

\title{
THE ASSESSMENT OF CORONAL TOOTH DISCOLORATION WITH USE OF MICROMEGA MTA OR MTA+ AS THE PULP-CAPPING MATERIAL $*$
}

\section{PULPA KAPAKLAMA MATERYALİ OLARAK MİKROMEGA MTA VE CERKAMED KULLANIMIYLA MEYDANA GELEN KORONAL DİŞ RENKLENMESİNİN DEĞERLENDİRİLMESİ}

\section{Dr. Öğr. Üyesi Cemile KEDİci ALP*}

\author{
Prof Dr. Oya BALA*
}

\section{Arş. Gör. Dr. Hanife ALTINIŞIK*}

\author{
Makale Kodu/Article code: 4591 \\ Makale Gönderilme tarihi; 24.09.2021 \\ Kabul Tarihi: 24.06.2021
}

Cemile Kedici Alp: ORCID ID: 0000-0002-1847-1367

DOI : $10.17567 /$ ataunidfd.956947

Hanife Altınışık: ORCID ID: 0000-0001-7430-4750

Oya Bala: ORCID ID: 0000 0001-5446-2583

\begin{abstract}
Aim: Mineral trioxide aggregate and calcium silicate cements have common usage in endodontics and restorative dentistry. However, MTA has some disadvantages such as long setting time, discoloration and cost. The treatment can not finish in a single visit because of long setting time. The aim of this study is to determine the discoloration of different materials on the coronal dentine.

Material and Methods: In this study, fifty bovine teeth were prepared and filled with Proroot MTA, MM-MTA, Biodentine, MTA+ (Cerkamed) placed and then sealed with a translusent composite. Unfilled samples were determined as a control groub. The specimens were kept at $37{ }^{\circ} \mathrm{C}$ in a dark environment. The color assessment was performed a with a spectrophotometer at different intervals (1th day, 1 month, 3 months, 9 months). The statistical analysis was performed by using One way Anova and Post-hoc Tukey tests.

Results: In the analysis of the tooth discoloration, the materials (Pro Root MTA, MM-MTA and MTA+ Cerkamed) were showed discoloration by the time. Biodentine showed tooth color stability because of zirconium oxide as a radiopacifier. The discoloration degree is very high between 1 th month and 3th month.

Conclusions: Different discoloration degrees of materials which are used in vital pulp treatments have been determined in this study. This criteria should also be taken into consideration if a dental vital pulp treatment isplanned in a tooth which may be anesthetically anxious.
\end{abstract}

Keywords: MTA, discoloration, vital pulp treatment

öz

Amaç: Mineral trioksit agregat (MTA) ve kalsiyum silikat bazlı simanlar endodonti ve restoratif tedavisinde sıklıkla kullanılmaktadır. Ancak MTA'nın sertleșme süresinin uzun olması, dişlerde renklenmeye sebep olması ve maliyetinin fazla olması gibi dezavantajları bulunmaktadır. Bu çalışmanın amacı farklı materyallerin koronal materyallerin koronal dentinde yaptığı renklenmeyi değerlendirmektir.

Gereç ve Yöntem: Bu çalışmada elli adet sığır dişinden örnekler hazırlanıp 5 gruba ayrıldı. Gruplara Proroot MTA, Biodentin, MM-MTA, MTA+ (Cerkamed) yerleştirildi ve daha sonra translusent kompozit ile restore edildi. Kontrol grubundaki örneklere herhangi bir işlem uygulanmadı. Örnekler karanlık ortamda $37^{\circ} \mathrm{C}$ de bekletildi. Renk değişimleri bir spektrofotometre ile farklı zaman aralıklarında (1. gün, 1 ay, 3 ay, 9 ay) ölçüldü. İstatistiksel analiz Tek yönlü Anova ve Post-hoc Tukey testleri kullanılarak yapıldı.

Bulgular: Çalışmada elde edilen verilere göre; Pro Root MTA, MM-MTA ve MTA+ (Cerkamed) kullanılan gruplarda zamanla renklenme gözlendi. Biodentinin içeriğinde bulunan zirkonyum oksit nedeniyle renklenme meydana gelmedi. Renklenme en fazla 1. ay ve 3. ayda görüldü.

Sonuç: Vital pulpa tedavilerinde kullanılan materyallerin diş renklenmesi üzerine etkisinin değerlendirildiği bu çalışmada; materyallerin farklı renklendirme dereceleri belirlenmiştir. Estetik açısından kaygı oluşabilecek bir dişte vital pulpa tedavisi planlanıyorsa bu kriter de göz önüne alınmalıdır.

Anahtar Kelimeler: MTA, renklenme, vital pulpa

*Gazi Üniversitesi, Diş Hekimliği Fakültesi, Restoratif Diș Tedavisi Dalı, Ankara.

₹ Bu araştırma "MTA+ (Cerkamed)'in Diş Renklenmesi Üzerine Etkisinin Değerlendirilmesi: İn Vitro Çalışma"

başlığıyla 1-3 Eylül 2017 tarihinde Eskişehir de düzenlenen Restoratif Diş Hekimliği Derneği 21. Uluslararası

Bilimsel Kongresinde poster bildirisi olarak sunulmuștur.

Kaynakça Bilgisi: Kedici Alp C, Altınışık H, Bala O. Pulpa kapaklama materyali olarak mikromega mta ve cerkamed kullanımıyla meydana gelen koronal diş renklenmesinin değerlendirilmesi. Atatürk Ǘniv Diş Hek Fak Derg 2021; 31: 571-5.

Citation Information: Kedici Alp C, Altinisik $H$, Bala O. The assessment of coronal tooth discoloration with use of micromega mta or mta+ as the pulpcapping material. J Dent Fac Atatürk Uni 2021; 31: 571-5. 


\section{INTRODUCTION}

Mineral trioxide aggregate (MTA) is very popular for vital pulp treatment, apexification of immature teeth and perforation repair ${ }^{1-3}$. MTA is a biologically safe material, but has some major disadvantages, namely its long setting time and the discoloration that it causes to both teeth and restorative materials ${ }^{4,5}$. A new calcium silicate-based material called Biodentine (Septodont, Saint-Maurdes Fossés, France) has been developed to overcome these disadvantages ${ }^{6,7}$. Biodentine contains calcium carbonate, tricalcium silicate liquid containing calcium chloride and zirconium oxide radiopacifier ${ }^{8}$. The developers added chloride to Biodentine to shorten its setting time to about 12 minutes $^{9}$. The zirconium oxide guarantees the color stability of Biodentine ${ }^{10}$. The rapid setting time means that treatment can be completed within a short period.

Micromega MTA (MM-MTA) is another newly developed calcium silicate cement, composed of dicalcium silicate, calcium sulfate dehydrate, tricalcium aluminate, tricalcium silicate, magnesium oxide, bismuth oxide and calcium carbonate $(\mathrm{CaCO} 3)^{11}$. The $\mathrm{CaCO}_{3}$ provides MM-MTA with a short setting time of about 20 minutes. MM-MTA can be used for practical applications because it is encapsulated. These beneficial characteristics make MM-MTA a good choice as a pulp-capping material ${ }^{12,13}$.

MTA+ is a new pulp-capping material composed of calcium oxide, silicon oxide, sodium oxide, iron oxide, aluminum oxide, potassium oxide, bismuth oxide, magnesium oxide, zirconium oxide and calcium phosphate. According to the manufacturer, MTA+ can be used in direct pulp-capping, root canal wall perforation, intracanal resorption, posterior root apex filling, pulp amputation, and the treatment of teeth with interrupted root development. The manufacturer claims that MTA+ is the only MTA product made of nanoparticles, and that the MTA+ particles are three times smaller than those of other MTAs. There are studies in the literature on the discoloration of Biodentine and ProRoot MTA. However, there is only one study concerning the discoloration of MM-MTA, and there is no information about MTA+ discoloration.

The aim of this in vitro study was to assess of the discoloration of MTA with nanoparticles (MTA+) when it is applied as a pulp-capping material.

\section{MATERIALS AND METHODS \\ Sample preparation}

The materials used in this in vitro study and their chemical compounds are shown in Table 1. We obtained 50 bovine central incisors and examined them under a microscope to check for fractures or structural defects ( $\times 3.5$ magnification). The crowns and roots were separated; then, the crowns were cleaned and polished with a polishing paste. We prepared $10 \times 10 \mathrm{~mm}$ disks from the facial surfaces of the crowns. We used a digital caliper to ensure that the thickness of each disk was standardized to 2.00$2.03 \mathrm{~mm}$. Cavities were induced (diameter $=5 \mathrm{~mm}$, depth $=1.5 \mathrm{~mm}$ ) in the centers of the dentinal surfaces (Figure 1). The specimens were then immersed in $1 \%$ sodium hypochlorite for 30 minutes, washed with water, and placed in $20 \%$ EDTA $(\mathrm{pH} 7.7)$ for 2 minutes ${ }^{14}$. The specimens were washed and dried with cotton pellet then were randomly assigned to five subgroups $(n=10)$.

Table 1. Materials used in the study

\begin{tabular}{|l|l|}
\hline Material/manufacturer & Chemical compounds \\
\hline Proroot MTA (Dentsply, & $\begin{array}{l}\text { Tricalcium silicate, dicalcium silicate, tricalcium } \\
\text { aluminate, tetracalcium aluminoferrite. }\end{array}$ \\
\hline Tulsa, OK, ABD) & $\begin{array}{l}\text { Potassium oxides, aluminium oxides, ferric oxides, } \\
\text { potassium sulphate, sodium sulphate }\end{array}$ \\
\hline $\begin{array}{l}\text { Company, Stalowa, Podiand) } \\
\text { Maurdestine (Septodont, Saint- }\end{array}$ & $\begin{array}{l}\text { Powder: tricalcium silicate, dicalcium silicate, calcium } \\
\text { carbonate and oxide, iron oxide, zirconium oxide } \\
\text { Liquid: calcium chloride, hydrosoluble polymer }\end{array}$ \\
\hline $\begin{array}{l}\text { MM-MTA (Micro Mega, } \\
\text { Besançon, France }\end{array}$ & $\begin{array}{l}\text { Tricalcium silicate, dicalcium silicate, tricalcium oxide, } \\
\text { tricalcium aluminate, tetracalcium aluminoferrite, } \\
\text { calcium sulphate, silicate oxide, bismuth oxide, } \\
\text { calcium carbonate }\end{array}$ \\
\hline
\end{tabular}

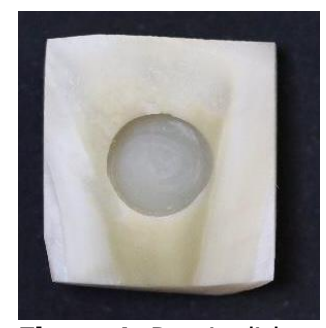

Figure 1. Dentin disk preparation

Group 1 was the control group, in which no MTA was applied. Groups 2-5 cavities were filled as follows: Group 2, ProRoot MTA; Group 3, MTA+; Group 4, Biodentine; and Group 5, MM-MTA. We then placed moist pellets on the samples and incubated them at $37^{\circ} \mathrm{C}$ for 24 hours.

After the 24 hour incubation period, dentinal surfaces were etched $37 \%$ orthophosphoric acid for 30

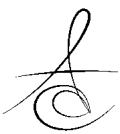


seconds, washed with water and dried. We applied adhesive (single-bond universal 3M ESPE, St. Paul MN, USA) and cured the samples using an LED light curing device (VALO Cordless LED curing light; Ultradent Products Inc., South Jordan, UT, USA). We then sealed the entire dentinal surface with a translucent composite (Amaris Translucent; Voco $\mathrm{GmbH}$, Cuxhaven, Germany) and stored the specimens in distilled water at $37^{\circ} \mathrm{C}$ in a dark environment.

After 24 hours, we dried the teeth with a cotton pellet and conducted color measurements of all of the specimens using a spectrophotometer (Easyshade, Vita Zahnfabrik, Bad Sackingen, Germany). We calibrated the instrument prior to taking the measurements for each group, which were repeated after 30, 90 and 180 days. The colors were evaluated with respect to the CIE formula ( $\left.L^{*} a^{*} b^{*}\right)(14)$; the differences $\left(\Delta \mathrm{E}_{\mathrm{ab}}\right.$ ) between the four color measurements were calculated as follows: $\Delta \mathrm{E}$ ab* $=\left[\left(\Delta \mathrm{L}^{*}\right)^{2}+\left(\Delta \mathrm{a}^{*}\right)^{2}\right.$ $\left.+\left(\Delta \mathrm{b}^{*}\right)^{2}\right]^{1 / 2}$.

\section{Statistical analysis}

We performed the data analysis SPSS software (ver. 17.0; IBM Corp., Armonk, NY, USA). We conducted a one-way analysis of variance (ANOVA) to evaluate whether the mean differences between $\Delta \mathrm{E}$ for each group were statistically significant. When the p-values in the one-way ANOVA were statistically significant, we used a post-hoc Tukey HSD test to establish the groups responsible for the differences. A $p$ value of less than 0.05 was noted to be statistically significant.

\section{RESULTS}

Table 2 indicates $\Delta \mathrm{E}$ measurements regarding for groups and follow-up times. Figure 2 shows a image of a specimen from each group at the different time point.

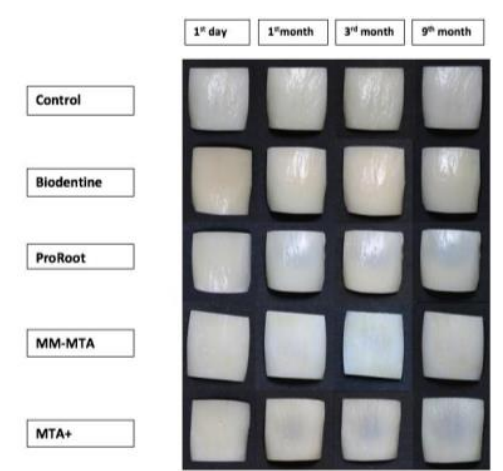

Figure 2. A spectrophotometric image of a tooth from each group at the different time poin
There were no statistically differences between the $\Delta \mathrm{E}$ levels of the control and Biodentine groups at each time point $(p=0.075 / p=0.361)$.

There were statistically significant differences among ProRoot, MTA+ and MM-MTA groups in $\triangle \mathrm{E}$ levels at each time point $(p<0.001)$. The samples in the ProRoot group showed more discoloration after 3 months than after 1 month $(p<0.001)$. In the MTA+ and MM-MTA groups, there was more discoloration after 3 and 9 months, respectively, than after 1 month $(p<0.001)$.

Table 2. $\Delta E$ measurements regarding for groups and followup times

\begin{tabular}{|c|c|c|c|c|c|}
\hline & $1^{\text {st }}$ day & $\mathrm{l}^{\text {st }}$ month & $3^{\text {rd }}$ month & $9^{\text {th }}$ month & p-value ${ }^{\dagger}$ \\
\hline Control & $2.18 \pm 0.84^{A, a}$ & $3.34 \pm 2.66^{A .3}$ & $6.16 \pm 4.20^{A, a}$ & $8.41 \pm 6.46^{A, A, A}$ & 0.075 \\
\hline ProRoot & $3.84 \pm 2.40^{A, 3}$ & $11.08 \pm 3.71^{\mathrm{B}, \mathrm{b}}$ & $15.76 \pm 2.01^{B /}$ & $15.24 \pm 3.01^{A, C, b, c}$ & $<0.001$ \\
\hline MTA+ & $4.04 \pm 3.97^{A, a}$ & $17.16 \pm 3.24^{\mathrm{c} b}$ & $23.02 \pm 3.72^{\mathrm{C} f}$ & $22.76 \pm 4.35^{D, f}$ & $<0.001$ \\
\hline Biodentine & $2.33 \pm 1.42^{\mathrm{A}, \mathrm{a}}$ & $2.92 \pm 1.50^{\mathrm{As}}$ & $5.12 \pm 3.64^{\mathrm{A}, \mathrm{a}}$ & $5.58 \pm 4.29^{\mathrm{Ba}}$ & 0.361 \\
\hline MM-MTA & $2.40 \pm 2.02^{A, 3}$ & $7.99 \pm 2.75^{\mathrm{B}, 6}$ & $15.72 \pm 3.34^{\mathrm{B} f}$ & $17.96 \pm 5.22 \mathrm{C}, \mathrm{D}, \mathrm{c}$ & $<0.001$ \\
\hline p-value * & 0.239 & $<0.001$ & $<0.001$ & $<0.001$ & \\
\hline
\end{tabular}

\section{DISCUSSION}

MTA is the best pulp-capping material currently available. Histologically, MTA forms a better dentin bridge than $\mathrm{Ca}(\mathrm{OH})^{15}$. However, tooth discoloration, which is undesirable in esthetic terms, is inevitable when conventional MTA is used as the pulp-capping material. In this in vitro study, we investigated the discoloration effects of four pulp-capping materials. There are many reports of tooth discoloration following MTA treatment in the literature, but there are no studies concerning discoloration due to MMMTA and MTA+.

Both bovine and human incisors have been used in MTA discoloration studies ${ }^{9}{ }^{16}$. In this study, we decided not to use human tissue for ethical reasons. Hence, we used bovine incisors taken from animals that had been slaughtered for consumption. The texture of bovine teeth tissue is like to human teeth, and it is easier to prepare standard specimens from bovine teeth.

ISO 9241-302 recommends calculating color differences using the three-dimensional CIE L*a*b* and CIE 2000 color measurement formulas; we used the former formula to evaluate discoloration in this study. Although CIE2000 is newer, the L*a*b* formula is still used in many dentistry color studies. 
The results of our study showed that MM-MTA, MTA+ and ProRoot MTA all cause significant discoloration, which increases over time. In these cases, the discoloration may be caused by bismuth oxide, which all three of these MTAs contain (serving as a radiopacifier). The oxidation of heavy metal oxides, such as iron oxide and, particularly, bismuth oxide may cause discoloration. There are several factors that contribute to discoloration in the case of bismuth oxide: first, oxidized bismuth oxide may react with carbon dioxide in the air to produce bismuth carbonate, resulting in discoloration. It has also been reported that bismuth oxide undergoes thermal dissociation at high temperatures, yielding metallic bismuth and oxygen ${ }^{17}$, and that bismuth oxide is converted to a black precipitate when it interacts with dentin collagen ${ }^{18}$. We used a high-intensity light curing device to polymerize the bonding agent in this study. This may have contributed to the increase in temperature, and hence the increase in discoloration.

Only one study reported that Biodentine may show discoloration after 1 year. The other studies reported no discoloration of Biodentine, which accords with the present study. The radiopacifier in Biodentine is zirconium oxide, which does not cause discoloration. To prevent discoloration, it may be preferable to use zirconium oxide instead of bismuth oxide in future silicate cements.

There was more discoloration in the MTA+ group than in the Pro Root and MM-MTA groups in this study, especially during the first month, in which dramatic discoloration occurred. As mentioned previously, the manufacturer claims that MTA+ is composed of nanoparticles that are three times smaller than those in other MTAs. The nanoparticles in MTA+ may penetrate deeper into the dentin, and then react to cause more discoloration.

MM-MTA is a newly developed, fast-setting, encapsulated form of MTA that is easy to use. There have been some studies on MM-MTA ${ }^{11-13}$, but to the best of our knowledge only one report has detailed MM-MTA discoloration. In contrast to this study, Dettwiler et al. ${ }^{15}$ reported no significant color change in MM-MTA or other calcium silicate cements containing bismuth oxide. However, their results contradict many other studies. In most previous studies on MTA, the samples were set by being placed on moist pellets and then incubated at $37^{\circ} \mathrm{C}$ under $100 \%$ humidity for 24 hours, whereas Dettwiler et al..$^{15}$ sealed the cavities with a dual-curing composite resin self-adhesive immediately after applying the MTA, i.e., without waiting for it to set. This immediate sealing of the MTA may have reduced oxidation of the bismuth oxide, thus preventing discoloration.

\section{CONCLUSION}

In this in vitro study, we found that, in terms of discoloration, it is safer to use zirconium oxide rather than bismuth oxide as a radiopacifier for MTAs. In particular, we observed more discoloration when using a nanoparticle-based MTA containing bismuth oxide.

Acknowledgements

The authors deny any conflicts of interest related to this study.

Disclosure Statement:

No potential conflict of interest was reported by the authors

\section{REFERENCES}

1. Bortoluzzi EA, Araujo GS, Guerreiro Tanomaru JM, Tanomaru-Filho M. Marginal gingiva discoloration by gray MTA: a case report. J Endod 2007;33:3257.

2. Parirokh $M$, Torabinejad $M$. Mineral trioxide aggregate: a comprehensive literature review--Part III: Clinical applications, drawbacks, and mechanism of action. J Endod 2010;36:400-13.

3. Yılmaz F, Kalaycı A, Melis A. Trikalsiyum silikat içerikli üç farklı endodontik materyalin sebep olduğu koronal diş renkleşmesinin spektrofotometrik analiz yöntemi ile değerlendirilmesi. Atatürk Üniv Diş Hek Fak Derg 2018;28:305-11.

4. Felman D, Parashos P. Coronal tooth discoloration and white mineral trioxide aggregate. J Endod 2013;39:484-7.

5. Belobrov I, Parashos P. Treatment of tooth discoloration after the use of white mineral trioxide aggregate. J Endod 2011;37:1017-20.

6. Zanini M, Sautier JM, Berdal A, Simon S. Biodentine induces immortalized murine pulp cell differentiation into odontoblast-like cells and stimulates biomineralization. J Endod 2012;38:1220-6.

7. Nowicka $A$, Lipski $M$, Parafiniuk M, Sporniak-Tutak K, Lichota D, Kosierkiewicz A, Kaczmarek W, Buczkowska-Radlinska J. Response of human dental pulp capped with biodentine and mineral trioxide aggregate. J Endod 2013;39:743-7.

8. Laurent P, Camps J, De Meo M, Dejou J, About I. Induction of specific cell responses to a 
$\mathrm{Ca}(3) \mathrm{SiO}(5)$-based posterior restorative material. Dent Mater 2008;24:1486-94.

9. Valles M, Roig M, Duran-Sindreu F, Martinez $S$, Mercade M. Color Stability of Teeth Restored with Biodentine: A 6-month In Vitro Study. J Endod 2015;41:1157-60.

10. Camilleri J, Sorrentino F, Damidot D. Investigation of the hydration and bioactivity of radiopacified tricalcium silicate cement, Biodentine and MTA Angelus. Dent Mater 2013;29:580-93.

11. Kum KY, Kim EC, Yoo YJ, Zhu Q, Safavi K, Bae KS, Chang SW. Trace metal contents of three tricalcium silicate materials: MTA Angelus, Micro Mega MTA and Bioaggregate. Int Endod J 2014;47:704-10.

12. Chang SW, Bae WJ, Yi JK, Lee S, Lee DW, Kum KY, Kim EC. Odontoblastic differentiation, inflammatory response, and angiogenic potential of 4 calcium silicate-based cements: micromega mta, proroot mta, retromta, and experimental calcium silicate cement. J Endod. 2015;41:1524-9.

13. Chang SW, Lee SY, Kum KY, Kim EC. Effects of ProRoot MTA, Bioaggregate, and Micromega MTA on odontoblastic differentiation in human dental pulp cells. J Endod 2014;40:113-8.

14. Lenherr $P$, Allgayer $N$, Weiger $R$, Filippi $A$, Attin $T$, Krastl G. Tooth discoloration induced by endodontic materials: a laboratory study. Int Endod J 2012;45:942-9.

15. Dettwiler CA, Walter M, Zaugg LK, Lenherr $P$, Weiger R, Krastl G. In vitro assessment of the tooth staining potential of endodontic materials in a bovine tooth model. Dent Traumatol 2016;32: 480-7.

16. Marciano MA, Costa RM, Camilleri J, Mondelli RF, Guimaraes BM, Duarte MA. Assessment of color stability of white mineral trioxide aggregate angelus and bismuth oxide in contact with tooth structure. J Endod 2014;40:1235-40.

17. Kang SH, Shin YS, Lee HS, Kim SO, Shin Y, Jung IY, Song JS. Color changes of teeth after treatment with various mineral trioxide aggregatebased materials: an ex vivo study. J Endod 2015;41:737-41.

18. Deepa VL, Dhamaraju B, Bollu IP, Balaji TS. Shear bond strength evaluation of resin composite bonded to three different liners: TheraCal LC, Biodentine, and resin-modified glass ionomer cement using universal adhesive: An in vitro study. J Conserv Dent 2016;19:166-70.

\section{Sorumlu Yazarın Yazışma Adresi}

Arş. Gör. Dr. Hanife Altınışık

Gazi Üniversitesi Diş Hekimliği Fakültesi

Restoratif Diş Tedavisi Anabilim Dalı, 06510

Emek, Ankara, Türkiye

e-mail: hanife.kamak@hotmail.com 